\title{
'L3C' Designation Doesn't Matter to Consumers
}

\section{Eden Blair (Bradley University) \\ Tanya Marcum (Bradley University) Veronika Koubova}

KEYWORDS: Entrepreneurship, Marketing, Legal.

\begin{abstract}
There has been limited empirical research on the impact of legal issues on entrepreneurial ventures, despite the fact that this impact appears to be great. The low-profit limited liability company (L3C) is a new business entity form in the U.S. that allows for firms to support a social and/or environmental mission without maximizing shareholder wealth. According to Intersector Partners, L3C (2014), as of August 24, 2014, there are 1,072 total active L3Cs in nine states and one tribal entity. While L3Cs were initially designed to encourage more program-related investments from foundations, many ventures are forming this entity because it better fits with their core social and/or environmental mission.
\end{abstract}

In this paper, we examine empirically whether the L3C designation can increase consumers' purchase intentions and perceptions of the designated business as one with primarily social or environmental impact. Our study used 330 participants, half of whom were identified as "green" consumers and half from the general population. Both groups were shown two descriptions of firms modified from real venture descriptions of existing L3Cs. One of these descriptions was given an LLC designation and one an L3C designation. One half of the participants were given a description of an L3C prior to being shown the L3C venture. Participants were asked to evaluate their likelihood to purchase from these two businesses and the perception that these firms supported social and/or environmental causes.

Our findings showed no significant difference between either the entity, company, or when a L3C description was given in either purchase intention or perception of business. Both dependent variables were significantly different for green consumers versus the general population and between genders. This finding suggests that the L3C currently has only limited usefulness as a signal of attractiveness to consumers, but greater education by states and ventures may increase this potential over time.

\section{Introduction}

Critical decisions made by every day by entrepreneurs have legal implications. Decisions such as entity formation choices, founders' agreements, contracts, intellectual property, regulations affecting a particular business and the selection of advisors have long-term legal, financial and strategic implications on entrepreneurs and their business ventures (Blair \& Marcum, in press). Entrepreneurship and the law are significantly intertwined from the very first thought by the entrepreneur about a business idea until long after the business has dissolved. Each entrepreneurial step along the way has potential legal implications and consequences. Thus, research merging these two academic areas is vitally important to the entrepreneurship discipline, as well as the discipline of law, and a rich field from which to develop research questions. There has been limited empirical research on the impact of legal issues on entrepreneurial ventures, despite the fact that this impact can be great (Luppino, 2007). We believe that this merger can answer many interesting research questions.

Many entrepreneurs are no longer interested in creating a business for just a financial motive but also want to be socially and/or environmentally sustainable. With an increasing desire to create social entrepreneurial ventures that do good for people and/or the planet, as well as make a profit, many U.S. entrepreneurs are trying to find business entity forms that do not require a maximization of shareholder wealth, as with a corporation or LLC, but that give greater flexibility and financial sustainability than a traditional non-profit form, such as an 501c(3) (Marcum \& Blair, 2012). The lowprofit limited liability company (L3C) is a new business entity form in the U.S. that allows for social, environmental and financial sustainability. 
One theory of why to choose an L3C over another entity form is that socially minded investors and customers will invest and do business with an entity that is doing something that is socially and/or environmentally beneficial and not just financially profitable (Marcum \& Blair, 2012; Nissim, 2013). While an L3C has certain positive tax implications for foundations that invest in them using program related investments (PRI), we argue that not all L3Cs are interested in these investments. One of the other reasons for using this entity form, we believe, is that the L3C designation in the business name can also signal to customers that its products or services do indeed meet some social or environmental goal. Thus, an L3C may use its designation for its branding capability.

In this paper, we examine whether the L3C designation can alert the public, investors and consumers that the designated business is one with social or environmental impact as the primary mission for the business and whether consumers value this impact when purchasing products from the firm. With proper education to its investors and customers of exactly what the L3C designation means, the business entity can attract new customers and investors to its business. Thus, the L3C designation is associated with "doing good," which may increase purchases from an L3C firm over others with similar products or services.

Our study is designed to explore whether customers are aware of the $\mathrm{L} 3 \mathrm{C}$ designation and use it to evaluate the overall brand quality of a product compared to firms with an LLC designation. Modified descriptions of two real L3C ventures were used for the study.

\section{Theory}

\section{Socially and environmentally conscious consumers}

A growing subset of consumers are concerned about environmental and/or social sustainability. According to the International Institute for Sustainable Development (2013), green consumers are sincere with their intentions and commitment to the green lifestyle, judge their environment practices as inadequate, and look for businesses that are taking substantial steps to improve their environmental impact. Research suggests these consumers care about the following issues. The first is whether the organization with which they are doing business is both ethical and sustainable (De Pelsmacker, Driesen, \& Rayp, 2005). Second is whether the products or services that they plan to consume are socially and/or environmentally sustainable (Awan, 2011). One way that consumers can demonstrate their concerns for these issues is by directing their consumption of products and services to those products and services that are made or provided by ethical and sustainable businesses that are also socially aware (De Pelsmacker et al., 2005). However, consumers often find it difficult to find accurate information about whether the business, its products or services actually meet some standard of making a substantial social or environmental impact (Castaldo, Perrini, Misani, \& Tencati, 2009).

Research on the likelihood that that social or green marketing affects a consumer's likelihood to purchase a product has generally found support. Borin, Cerf, \& Krishnan (2011) found that consumers reacted positively when the labeling of the products' environmental impact was positive and negatively when labeled negative compared to a neutral label, suggesting that a products' labeling matters for product evaluations. Other research found that consumers are willing to pay slightly more for products with environmentally conscious labeling (Saunders, Guenther, Kaye-Blake, Miller, \& Tait, 2010). A study of adolescents in Hong Kong found that social influence was the greatest factor in the likelihood to purchase environmentally friendly products, and encouraged marketing campaigns with an emotional appeal to purchase green products (Lee, 2008). In a longitudinal study of consumers' attitudes toward certified wood products from 1995 to 2000, researchers found that people are slightly less willing to pay as much of a premium on certified products, although they are more likely to pay a premium for higher quality products when they are also certified (Ozanne, 2003). In addition, the study suggests consumers had greater understanding of wood products' certification in 2000 than in 1995 and equal levels of trust in the certification. This research tends to support that clear labeling of products as environmentally friendly has a positive impact on consumers' willingness to purchase these products.

\section{The L3C designation}

Some states have enacted limited liability statutes, which include the low-profit limited liability company as an entity option (L3C). The L3C has many of the same attributes as its cousin the LLC, such as shielding its member owners from liabilities and the election of pass through federal taxation (Marcum \& Blair, 2012). An 
L3C must be created with its mission's focus to advance at least one cause that is environmental or social and must allow the entity to be profitable but also to engage in activities that are charitable in nature (Vitello, 2011).

The L3C entity is a creation of state legislative statute. As such, it must comply with the provisions in the statute requiring that the $\mathrm{L} 3 \mathrm{C}$ have as its primary purpose "charitable or educational" goals, and its secondary purpose a profit motive (Sertial, 2012). The L3C entity must not seek to advance political or legislative purposes (Vitello, 2011). In addition, private foundations can invest in L3C businesses that match their charitable goals. Program related investments [PRIs] are regulated by the Internal Revenue Code Section 4944(c), but if qualified, can lead the L3C to be financially sound (Marcum \& Blair, 2012; Weiler, 2011). PRIs allow private foundations to make prudent investments in L3Cs "that enables the foundation to generate a return from the nonprofit entity" (Sertial, 2012, p. 281) and still remain tax exempt.

The L3C entity is a type of limited liability company (LLC). As such, it resembles the LLC in several ways. First, the LLC allows for pass-through federal income tax treatment to the members of the LLC, similar to a partnership (Marcum \& Blair, 2011). Second, the LLC, like a corporation, allows for the limited liability for the debts of the business to the owners of the business (Fox \& Luna, 2005). However, unlike the LLC entity form, which is available in all 50 states, the L3C entity is available only in a select few states.

According to Intersector Partners, L3C, (2014) as of August 24, 2014, there are 1,072 total active L3Cs in Vermont, Michigan, Wyoming, Utah, Illinois, North Carolina (where the L3C law was repealed as of January 1, 2014), Louisiana, Maine, Rhode Island and the Oglala Sioux Tribe. This is an increase of 495 new L3Cs since March 2012 (Marcum \& Blair, 2012), suggesting an increase in the attractiveness and awareness of the entity form by businesses. As of January 1, 2014, North Carolina revised its LLC statute by removing the $\mathrm{L} 3 \mathrm{C}$ entity choice. According to a quote in Forbes from a task force member who drafted North Carolina's statute, the repeal of the L3C entity was to streamline the LLC statute (Field, 2014).

\section{The $\mathrm{L} 3 \mathrm{C}$ as a marketing tool}

We argue in this paper that the L3C entity form can be used as a method of brand identification. We argue that the $\mathrm{L} 3 \mathrm{C}$ designation might act as an easily identifiable brand element for these mission-driven organizations, especially for potential customers and investors, even for those ventures not interested in seeking PRIs. A brand is defined as the set of positive and negative attributes that people associate with an organization (Barringer \& Ireland, 2011). Thus, a brand may have positive attributes - like the firm being considered innovative, good response times to customers or a reputation for acting ethically towards its employees -or it may have negative attributes, such as a common perception among its consumers that its products break or that its livestock are poorly treated (Kotler, 2011). This brand is, in essence, the reputation of a firm and can lead consumers to develop great loyalty to a positive brand image or to avoid a business with a negative one (Barringer \& Ireland, 2011). Consumers perceive that a good brand is a guarantee about the quality of the business or its products or services (Baron \& Shane, 2008). A brand is often identified by a company trademark, such as a logo, slogan, product, service or company name (de Chernatony, 1999). A positive brand image is one of the most valuable assets of a firm, and many larger firms have staff devoted solely to brand management (Zyman \& Miller, 2000). Price, quality, convenience and brand familiarity are important and common factors used by consumers when determining what particular product or service they want to purchase (De Pelsmacker et al., 2005).

Brands are not developed overnight but take time (Nagy, Blair, \& Lohrke, 2014). Thus it may be difficult for a start-up entrepreneur's business to establish a brand (Choi \& Shepherd, 2005; Nagy et al., 2014), and most L3Cs, since they are a relatively new entity, are likely to be young ventures. Start-ups generally have not gained a brand reputation, so may lack a perception of legitimacy. This lack of legitimacy may make customers wary of purchasing products or services from that firm, since they are unaware of the reputation of the firm or the quality and value of its products and services (Choi \& Shepherd, 2005; Nagy et al., 2014). Without a reputation, customers have little means of knowing whether the company lives up to its promises such as high quality goods, an ethical reputation or good customer service (Pickett-Baker \& Ozaki, 2008).

We argue that brand recognition can be beneficial for an entity, and the L3C designation can signal that the venture is carrying out its social, environmental or other charitable missions (Marcum \& Blair, 2012). Many 
consumers are concerned with these social problems and may lend their allegiance to such businesses when they are perceived by the consumer as like-minded. State statutes require that all L3C entities have the "L3C" designation at the end of their business name, where it can easily and readily seen by consumers. This designation may signal to consumers that the business is an entity with social, environmental or other charitable missions, and they may also perceive this as a stamp of approval on the entity by the particular state government (Marcum \& Blair, 2012).

This brand recognition may matter especially for an organization that purports to have a social or charitable mission, such as an L3C. The L3C entity might identify a firm as one that follows sustainable practices in the venture's early stages. New mission-driven entities, due to the nature of being young, can give little evidence to customers about whether they truly meet social or environmental sustainability goals or are just committing "greenwashing," a public relations process that companies can use to convince its stakeholders that they are meeting these goals by misrepresenting a few minor efforts to be socially responsible as something that will have major impact (Leonidou \& Leonidou, 2011).

An L3C entity might signal to consumers that the venture has verified with the state governmental agency that they do meet an approved charitable or educational purpose. When a business has an L3C designation after its business name, the customer's perception with regards to the quality and certification that this business meets a social cause may well sway the customer to purchase the goods or services that the L3C business sells over its non-L3C competitors. For a start-up venture, this could mean the start of a reputation that does not exist otherwise due to its lack of experience in the market. As a customer perceives L3Cs equates to or means "good," that customer is more likely to purchase, even when the $\mathrm{L} 3 \mathrm{C}$ is young and has yet to increase its reputation in other ways related to its business operations.

Another reason that L3Cs might be an effective mode of branding is that the entity form signals that the state approves that it does follow its purported charitable or educational mission. The oversight of the L3C by a state agency suggests that the L3C has complied with state regulatory requirements and may be an indicator to consumers, investors, and more importantly, private foundations with money to invest in the L3C. At this time, there is little evidence to suggest that state agencies do or do not play an active oversight or investigatory role once an $\mathrm{L} 3 \mathrm{C}$ is formed. However, this may have little impact on the perception by the L3C's stakeholders that it does do oversight. With proper education by the $\mathrm{L} 3 \mathrm{C}$ to its stakeholders of what the entity signals, this could be viewed as a "stamp of approval" or certification similar to that of the Good Housekeeping Seal of Approval, Underwriters Laboratory (UL), or a Leadership in Energy and Environmental Design (LEED) Certification. We argue that the L3C letters behind the name of an entity could be a signal to these stakeholders certifying that the social entity is engaged in a charitable purpose.

Since no research to our knowledge has examined either a consumers' awareness of the L3C designation or its ability, we decided to develop exploratory hypotheses around the $\mathrm{L} 3 \mathrm{C}$ as a reliable brand identifier. First, does the business entity form matter to consumers, and will it effect their likelihood to purchase this product or change their impression of the venture's support of social and or environmental causes? Second, would the entity form matter more to consumers when they are provided with information about L3Cs in general?

\section{Study}

In an attempt to improve the chances of a representative sample, we purchased a panel of participants (18 years and older, residing in the United States) from Qualtrics, an online survey and marketing firm that provides large panels of participants to third parties for online surveys. Half ( $n=165)$ of these participants were identified by Qualtrics as being more likely to purchase green products. The other half $(n=165)$ were considered to be from the general population of participants. This gave us a total of 330 participants, with 163 or $49.4 \%$ female. The average age of the participants was 48.0 years (s.d. = 17.2), average education was "some college" and average income ranged from "\$40,000 - \$49,000." The participants were given incentives to participate in the survey by Qualtrics. Participants were also asked to score their prior knowledge of the L3C entity form (Likert 1-4 scale, "None", "A Little", "Some", "A Lot"). Scores ranged between 2-4 and averaged 3.08 "Some").

\section{Procedure}

Participants were shown two companies, "Sky's the 
Limit" and "Baker" with permission from the ventures prior to the creation of the survey instrument. Both ventures' descriptions were based on real L3Cs, but the descriptions were modified and the names changed. Sky's the Limit was described as a:

"[M]arket for Midwestern farmers and healthy food for organizations. Through the sale of fine quality, locally focused products based on healthy fresh food, much of which is grown and processed in its new state-of-the-art facility, customers will receive a significant quantity of healthy food; a market will open for the purchase of locally grown food; and organizations will have access to healthy local food."

\section{Baker was described as a:}

"Small, 65-acre farm in the foothills of New England. The farm is committed to preserving our area's working, agricultural landscape and raising happy, wholesome animals on a sustainable scale. Its animals are pastured in fields and ranged through a forest and at the top of a watershed. We practice rotational grazing, improve soil through smart animal husbandry, and otherwise keep our environmental impact very low, in part by doing a lot by hand. By keeping the farm small and methods sustainable, the farm offers high quality meat, eggs and maple syrup produced right here in New England."

Participants were shown both descriptions with one randomly identified as an LLC and one as an L3C. In half of the cases, the $\mathrm{L} 3 \mathrm{C}$ was described in more detail before they were given the business description:

"The following description is of an entity type found in many states in the US of which you may not be aware. An L3C (Low Profit Limited Liability Company) is an entity created with the mission to advance one or more causes that are social or environmental in nature and to allow the entity to earn a profit while engaged in its charitable activities. It is viewed as an entity structure that is an ideal solution for the entrepreneurial, missiondriven social venture."

Participants were asked to evaluate the venture on two factors, the likelihood they would purchase this product, if they lived in the geographic area (Likert 1-7 scale, with 7 = "Highly Likely") and the likelihood that this venture supports social or environmental causes (Likert 1-7 scale, with 7 = "Highly Likely").

Demographic variables were collected, including gender, age, income level and state of residence. Participants completed the HEP NEP (Human Exception Paradigm - New Environment Paradigm) questionnaire to judge their attitudes towards the environment and to others (Dunlap \& Van Liere, 1978). The mean score (scored on a Likert Scale of 1-5) was a 42.1 , suggesting that on average, the sample believed that humans must at least partially consider the resources they use.

\section{Results}

A $2 \times 2 \times 2 \times 2 \times 2$ (company $\times$ entity $\times$ description of L3C $x$ purchaser type $x$ gender) ANOVA was completed for both dependent variables. Results for the first dependent variable, likelihood to purchase the product, suggest no significant difference between the ratings given for either company nor any interaction effects. Significant main effects were found for both different purchaser types $\mathrm{F}(1,659)=67.4 p<.001$ and gender $F(1,659)=9.3, p<.01$. This suggests that people who self-identify as likely to purchase green products were more likely to be willing to purchase these products. This is also the case for women participants, who on average evaluated their likelihood to purchase higher than men. A significant interaction effect was found between gender and type of purchaser $F(2,658)=4.7$, $p<.05$. Table 1 shows the descriptive means for these factors. 


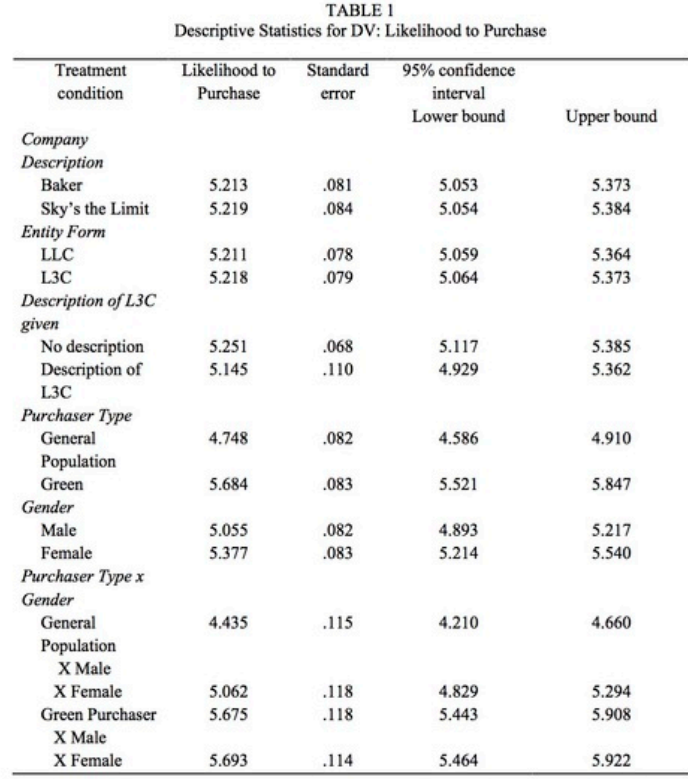

A similar ANOVA was completed for the dependent variable that measured the participants' perception of the likelihood the company support environmental or social causes. Again, no main effects were found for company, entity or education on the L3C form. Main effects were found for purchaser type $F(1,659)=55.5$, $p<.001$ and gender $F(1,659)=14.0, p<.001$ and $a$ significant interaction effect was also found for these two variables $F(2,658)=7.0, p<.01$. This suggests that green purchasers were more likely to perceive that these companies were more likely to support social or environmental causes than purchasers from the general population and women were more like to perceive this support than men. The interaction effect suggests that women green purchasers are the most likely to perceive this likelihood of support. See Table 2 for descriptive means.
TABLE 2

\begin{tabular}{|c|c|c|c|c|}
\hline $\begin{array}{l}\text { Treatment } \\
\text { condition }\end{array}$ & $\begin{array}{l}\text { Likelihood to } \\
\text { Purchase }\end{array}$ & $\begin{array}{l}\text { Standard } \\
\text { error }\end{array}$ & $\begin{array}{l}95 \% \text { confidence } \\
\text { interval } \\
\text { Lower bound }\end{array}$ & Upper bound \\
\hline \multicolumn{5}{|l|}{ Company } \\
\hline \multicolumn{5}{|l|}{ Description } \\
\hline Baker & 5.372 & .078 & 5.219 & 5.525 \\
\hline Sky's the Limit & 5.273 & .081 & 5.115 & 5.431 \\
\hline \multicolumn{5}{|l|}{ Entity Form } \\
\hline LLC & 5.290 & .074 & 5.144 & 5.436 \\
\hline $\mathrm{L} 3 \mathrm{C}$ & 5.339 & .075 & 5.191 & 5.487 \\
\hline \multicolumn{5}{|l|}{ Description of $L 3 C$} \\
\hline $\begin{array}{l}\text { given } \\
\text { No description }\end{array}$ & 5.339 & .065 & 5.210 & 5.467 \\
\hline $\begin{array}{l}\text { Description of } \\
\text { L3C }\end{array}$ & 5.290 & .106 & 5.082 & 5.498 \\
\hline \multicolumn{5}{|l|}{ Purchaser Type } \\
\hline $\begin{array}{l}\text { General } \\
\text { Population }\end{array}$ & 4.923 & .079 & 5.210 & 5.467 \\
\hline \multicolumn{5}{|l|}{ Population } \\
\hline Green & 5.722 & .080 & 5.082 & 5.498 \\
\hline \multicolumn{5}{|l|}{ Gender } \\
\hline Male & 5.130 & .079 & 4.893 & 5.217 \\
\hline Female & 5.515 & .080 & 5.358 & 5.671 \\
\hline \multicolumn{5}{|l|}{ Purchaser Typex } \\
\hline \multicolumn{5}{|l|}{ Gender } \\
\hline General & 4.566 & .110 & 4.350 & 4.782 \\
\hline \multicolumn{5}{|l|}{ Population } \\
\hline $\begin{array}{l}\mathrm{x} \text { Male } \\
\mathrm{xFemale}\end{array}$ & 5.280 & .114 & 5.057 & 5.503 \\
\hline $\begin{array}{l}\text { Green Purchaser } \\
\text { x Male }\end{array}$ & 5.695 & .114 & 5.472 & 5.918 \\
\hline x Female & 5.749 & .112 & 5.530 & 5.969 \\
\hline
\end{tabular}

As our results showed no main effects for these entity forms, we completed a post hoc $2 \times 2 \times 2 \times 2$ (company $x$ entity $x$ description of $L 3 C x$ residing in state with an L3C states) ANOVA that included differentiating between states that have statutes for L3Cs and those that do not, as they may be more sensitive to the L3C designation. There was no main effect for L3C state residency for either dependent variable. There was a significant interaction effect between description of an $\mathrm{L} 3 \mathrm{C}$ and residence $\mathrm{F}(2,658)=4.56, p<.05$. Surprisingly, with no description of an L3C was given, those residing in states with $\mathrm{L} 3 \mathrm{Cs}$ were less likely to purchase from an $\mathrm{L} 3 \mathrm{C}$ than those in other states (means were 4.712 vs 5.318 ) and slightly more likely to purchase when educated on L3Cs that those in other states (means of 5.205 vs. 5.105). This result, especially for the first instance, is difficult to interpret, and may be a result of geographical preferences or merely an artifact of the study.

\section{Implications}

Our results suggest that the $\mathrm{L} 3 \mathrm{C}$ designation provides no different signal than that of the LLC. This occurs 
even when a description of an $L 3 C$ is given to the participant immediately before his or her evaluation of the venture. None of the demographic variables we measured appeared to make a difference in an individual's perception between an L3C and an LLC. After six years since the first L3C statute and over 1000 L3Cs formed, this suggests that states and L3C advocates have not adequately educated consumers on the value of purchasing products from firms that value social and/or environmental causes enough to make them their social mission. As stated earlier, the description for our two ventures came from real L3Cs, and we did find that these descriptions were evaluated higher by two groups, green purchasers and women, but the business entity had no significant effect.

We encourage $\mathrm{L} 3 \mathrm{C}$ advocates to improve the marketing and awareness of the $\mathrm{L} 3 \mathrm{C}$ designation. If clearly identified with product and company, the designation could have the ability to quickly help a consumer judge the perceived "goodness" of a venture and its products and make purchasing decisions accordingly. In prior research (Marcum and Blair, 2012) an examination of L3C websites found that $36.8 \%$ of L3Cs with a website educated consumers on the designation, with only $68.4 \%$ even identifying themselves as an L3C. These ventures could also market and educate their consumers about the importance of the L3C designation.

State governments can also improve the branding potential of these ventures by doing a more thorough and transparent job of assessing the claims made by these ventures that do meet the environmental or social mission. As new firms are more susceptible to failure as they have not been able to develop a reputation (Nagy et al., 2014), state governments have an incentive to support certification to improve the ventures' chances for success. If ventures fail, jobs are lost, taxes are not paid and regulatory fees are not paid.

Green purchasers and women are more likely to purchase based on the description they were given, but did not use the entity choice as a factor in their decision. This suggests they care about the items they purchase and read the description. Both groups may be good consumer subsets to whom to market more extensively, thus being more efficient in their marketing resources.

We feel that the research field of legal issues in entrepreneurial firms has many opportunities for gathering good empirical data with both academic and applied implications. This study was one area in which this field can be examined. As federal and state legislative bodies create legislation with significant policy and tax implications, assessing the impact of these decisions on entrepreneurs should be thoroughly evaluated and reported. In some states, entrepreneurs pay significantly more to form their venture as an L3C than they would for forming a corporation, at the early start-up stage of the venture-creation process where they often have little cash available (Blair, Marcum, \& Fry, 2010). This may also affect their decision to form. States may also want to publicize (and possibly better regulate) L3Cs and other social venture entities more to help encourage their development. With little data in these areas to support or oppose these issues, many states are making blind decisions. This research may help states make better data-driven decisions on how to manage and regulate entity formation and the resources needed to publicize it. In addition, the L3C owners may want to focus more energy on educating their current and potential customers on this entity formation and why it matters.

\section{Future Research}

As stated previously, research suggests and encourages clearer identification of a product's environmental or social impact that is easily accessible by the consumer. This suggests that consumers are searching for a way to make these evaluations in an easy fashion. Examining how the identification of a venture as a B Corp - which, despite its name, is not an business entity form but a certification for firms that measures and certifies their environmental and social impact - may have more brand awareness than the entity form and may yield different results.

\section{Conclusion}

A socially minded entrepreneur may choose to form the business venture as an L3C entity as this business form for its potential as a valuable and relatively inexpensive branding tool. If an entrepreneur is seeking to be environmentally conscious, other for-profit legal entities likely offer no branding benefit currently for their potential consumers or investors like the L3C designation can provide for the social enterprise. However, at this time the L3C designation alone, without sufficient education and awareness, may not be enough. L3C owners should not assume that general public is aware of the designation or use it in business decisions. 
This may change if L3Cs, their advocates, and states improve their education and marketing energies.

\section{References}

Awan, U. (2011). Green marketing: Marketing strategies for the Swedish energy companies. International Journal of Industrial Marketing, 1(2), 1-19.

Baron, R. A., \& Shane, S. A. (2008).Entrepreneurship : A process perspective (2nd ed.). Mason $(\mathrm{OH})$ : Thomson/South-Western.

Barringer, B. R., \& Ireland, D. (2011).Entrepreneurship: Successfully Launching New Ventures (4th ed.). Boston, MA: Prentice Hall.

Blair, E. S., \& Marcum, T. M. (in press). Heed our advice: Exploring how professionals guide small business owners in startup entity choice. Journal of Small Business Management.

Blair, E. S., Marcum, T. M., \& Fry, F. (2010). The disproportionate costs of forming LLCs vs. Corporations: The impact on small firm liability protection. Journal of Small Business Strategy, 20(2), 23-42.

Borin, N., Cerf, D. C., \& Krishnan, R. (2011). Consumer effects of environmental impact in product labeling. Journal of Consumer Marketing, 28(1), 76-86. doi:10.1108/07363761111101976

Castaldo, S., Perrini, F., Misani, N., \& Tencati, A. (2009). The missing link between corporate social responsibility and consumer trust: The case of fair trade products. Journal of Business Ethics, 84(1), 1-15.

Choi, Y. R., \& Shepherd, D. A. (2005). Stakeholder perceptions of age and other dimensions of newness. Journal of Management, 31(4), 573.

De Chernatony, L. (1999). Brand management through narrowing the gap between brand identity and brand reputation. Journal of Marketing Management, 15(1-3), 157-179.

De Pelsmacker, P., Driesen, L., \& Rayp, G. (2005). Do consumers care about ethics? Willingness to pay for fairtrade coffee. Journal of Consumer Affairs, 39(2), 363-385. doi:10.1111/j.1745-6606.2005.00019.x

Dunlap, R. E., \& Van Liere, K. D. (1978). The "new environmental paradigm." The Journal of Environmental Education, 9(4), 10-19.

Field, A. (2014). North Carolina officially abolishes the L3C. Retrieved November 14, 2014 from http://www.for bes.com/sites/annefield/2014/01/11/north-carolinaofficially-abolishes-the-|3c/

Fox, W. F., \& Luna, L. (2005). Do limited liability companies explain declining state corporate tax revenues? Public Finance Review, 33(6), 690-720. doi:10.1177/1091142105279333

Intersector Partners, L3C. (2014). Here's the latest L3C Tally (updated monthly) as of: August 24, 2014.

Kotler, P. (2011). Marketing insights from $A$ to Z: 80 concepts every manager needs to know. John Wiley and Sons.

Lee, K. (2008). Opportunities for green marketing: young consumers. Marketing Intelligence \& Planning, 26(6), 573-586. doi:10.1108/02634500810902839

Leonidou, C. N., \& Leonidou, L. C. (2011). Research into environmental marketing/management: a bibliographic analysis. European Journal of Marketing, 45(1/2), 68-103. doi:10.1108/03090561111095603

Luppino, A. J. (2007). Minding more than our own business: Educating entrepreneurial lawyers through Law School-Business School collaborations. Western New England Law Review, 30, 151-222.

Marcum, T. M., \& Blair, E. S. (2011). Entrepreneurial Decisions and Legal Issues in Early Venture Stages: Advice That Shouldn't Be Ignored. Business Horizons, $54,143-152$.

Marcum, T. M., \& Blair, E. S. (2012). In search of a unique identity: The $\mathrm{L} 3 \mathrm{C}$ as a socially recognized brand. Transactions, 14, 79-603.

Nagy, B. G., Blair, E. S., \& Lohrke, F. T. (2014). Developing a scale to measure liabilities and assets of newness after start-up. International Entrepreneurship and Management Journal, 10(2), 277-295. doi:10.1007/s11365-012-0219-2

Nissim, B. H. (2013). A mutually beneficial relationship: How the low-profit limited liability company can build a brand and grow America's wind energy infrastructure. 
North Dakota Joural of Ethics \& Public Policy, 27, 247-273.

Ozanne, L. K. V., Richard P. (2003). Certification from the U.S. consumer perspective: A comparison from 1995 and 2000. Forest Products Journal, 53(3), 13-21.

Pickett-Baker, J., \& Ozaki, R. (2008). Pro-environmental products: marketing influence on consumer purchase decision. Journal of Consumer Marketing, 25(5), 281-293. doi:10.1108/07363760810890516

Saunders, C., Guenther, M., Kaye-Blake, W., Miller, S., \& Tait, P. R. (2010). Consumer attitudes towards sustainability attributes on food labels. Retrieved from http://researcharchive.lincoln.ac.nz/handle/10182/3377

Sertial, H. (2012). Hybrid entities: Distributing profits with a purpose. Fordham Journal of Corporate and Financial Law, 17, 261.

Vitello, C. (2011). Introducing the low-profit limited liability company (L3C): The new kid on the block. Loyola Consumer Law Review, 23, 565.

Weiler, C. N. (2011). The low-profit limited liability company has arrived in Louisiana. Louisiana Business Journal, 59, 98-99.

Zyman, S., \& Miller, S. (2000). Building brand-width: Closing the sale online. HarperInformation. Retrieved from http://dl.acm.org/citation.cfm?id=557407 